\title{
Relacje wpisów w dziale drugim księgi wieczystej do wpisu wieczystoksięgowego ostrzeżenia o prowadzeniu postępowania restrukturyzacyjnego
}

\author{
Relations of entries in the second section of the land register \\ for the entry of perpetual-accounting warning about \\ the running restructuring proceedings
}

\section{dr Daniel Jakimiec}

E-mail: danieljakimiec@ onet.pl; nr ORCID: 0000-0003-1024-5759

\begin{abstract}
Streszczenie
Wpis wieczystoksięgowy ostrzeżenia o prowadzeniu postępowania restrukturyzacyjnego służy prawidłowemu podjęciu czynności procesowych i materialnoprawnych uczestników postępowania restrukturyzacyjnego. Wpis ten zapobiega nieważności tych czynności. Treść tego wpisu wieczystoksięgowego umożliwia sądowi oraz notariuszowi ocenę legitymacji materialnej i procesowej dłużnika będącego uczestnikiem postępowania restrukturyzacyjnego do dokonania czynności rozporządzającej prawem do nieruchomości. Przedmiotowe ostrzeżenie ogranicza w sferze procesowej i materialnoprawnej właściciela, użytkownika wieczystego oraz uprawnionego z tytułu spółdzielczego własnościowego prawa do lokalu w czynnościach prawnych dotyczących nieruchomości, chroniąc interes prawny wierzycieli uczestników postępowania restrukturyzacyjnego, jak i innych podmiotów zainteresowanych stanem prawnym nieruchomości. Stosownie do art. 8 ustawy o księgach wieczystych i hipotece wpis ten bowiem uchyla działanie rękojmi wiary publicznej ksiąg wieczystych.
\end{abstract}

Słowa kluczowe: postępowanie restrukturyzacyjne, księgi wieczyste, wpis wieczystoksięgowy ostrzeżenia, właściciel, użytkownik wieczysty oraz uprawniony z tytułu spółdzielczego własnościowego prawa do lokalu

\section{Summary}

The perpetual-accounting entry of warning about the running restructuring proceedings is used for correct taking the activity of procedural and financial-legal participants of restructuring proceedings. This entry prevents the nullity of these activities. Through contents of this perpetual-accounting entry the court and the notary can assess the debtor being a participant in restructuring proceedings for performing an act the financial and procedural card disposing of the right to the real estate. The of objects warning is limiting the owner in the procedural and financial-legal sphere, of user perpetual and authorised on account of the cooperative property law to premises in the acts in law concerning the real estate protecting the legal interest of creditors of participants in restructuring proceedings, as well as interested other operators with legal status of the real estate. According to the Art. of 8 Act on Land and Mortgage Registers and Mortgages because this entry is repealing the effect of the statutory warranty of public comrades of the land register.

Key words: restructuring proceedings, land register, perpetual-accounting entry of the warning, owner, user perpetual and authorised on account of the cooperative property right to residential premises

JEL: K25

Str. 2-9

\section{Bibliografia}


Adamus, R. (2015). Prawo restrukturyzacyjne. Warszawa: C.H. Beck.

Broniewicz, W. (2006). Postępowanie cywilne w zarysie. Warszawa: Lexis Nexis.

Czech, T. (2014). Księgi wieczyste i hipoteka. Komentarz. Warszawa: Lexis exis.

Deneka, M. (2012). Ksieggi wieczyste. Zasady materialnoprawne. Warszawa: Lexis Nexis.

Gniewek, E. (2017). Ksiegi wieczyste. Komentarz. Warszawa: C.H. Beck.

Korzan, K. (2004). Postępowanie nieprocesowe. Warszawa: C.H. Beck.

Kućka, M. (2014). J. Pisuliński (red.). Ustawa o księgach wieczystych i hipotece. Postępowanie wieczystoksięgowe. Warszawa: Lexis Nexis. Maziarz, A. (2012). Formalizm w postępowaniu wieczystoksięgowym. Warszawa: Difin.

Pietrzykowski, K. (red.). (2011). Kodeks cywilny. Komentarz (t. 1), Warszawa: C.H. Beck.

Pisuliński, J. (red.). (2014). Ustawa o księgach wieczystych i hipotece. Postępowanie wieczystoksięgowe. Warszawa: Lexis Nexis.

Resich, Z. (2009). W: Jodłowski, J., Resich Z., Lapierre, J., Misiuk-Jodłowska, T., Weitz, K. (2009). Postepowanie cywilne. Warszawa: Lexis Nexis.

Skowrońska-Bocian, E. (2011). W: K. Pietrzykowski, K. (red.). (2015). Kodeks cywilny. Komentarz (t. 1), Warszawa: C.H. Beck.

Zimmerman, P. (2016). Prawo upadłościowe. Prawo restrukturyzacyjne. Komentarz. Warszawa: C.H. Beck. 